\title{
Bitlis Yerel Gazetelerinin Yenileşme Pratikleri
}

\section{Bitlis Local Newspapers' Innovation Practices}

\author{
Aziz Coşkun a, * \\ ${ }^{a}$ Öğr. Gör., Bitlis Eren Üniversitesi, Güroymak Meslek Yüksekokulu, Pazarlama ve Reklamcılık Bölümü, Bitlis/Türkiye. \\ ORCID: 0000-0002-8486-8266
}

\section{MAKALE BİLGİSİ \\ Makale Geçmişi: \\ Başvuru tarihi: 31 Aralık 2020 \\ Düzeltme tarihi: 6 Mayıs 2021 \\ Kabul tarihi: 16 Mayıs 2021}

Anahtar Kelimeler:

İnternet

İnternet Gazeteciliği

Yerel Medya

İçerik Analizi

Bitlis

\section{ARTICLE INFO}

Article history:

Received: December 31, 2020

Received in revised form: May 6, 2021

Accepted: May 16, 2021

\section{Keywords:}

Internet

Internet Journalism

Local Media

Content Analysis

Bitlis
ÖZ

İnternet gazeteciliği, gazeteciliğin çeşitli yöntemlerinin kullanılarak bilginin yazılı, görsel ya da işitsel olarak okuyucu kitlesine ulaştırılmasıdır. Yerel medyalar; internet gazeteciliği sayesinde kendi yörelerinde yaşanan gelişmeleri, sorunları ve kendi yerel kültürleri ile ilgili değerleri dünyanın her yerine ulaştırabilme firsatı yakalamışlardır. Bu tespitlerden hareketle internet gazeteciliğinin her geçen önem kazandığı yeni medya dünyasında, Bitlis il merkezindeki yerel gazetelerin yenileşme pratikleri değerlendirme konusu olarak seçilmiştir. Yöntem bağlamında, Bitlis il merkezinde günlük yayımlanan ilgili gazetelerinin internet siteleri 09-15 Kasım 2020 tarihleri arasında bir haftalık sürede, içerik analizi ile incelenmiştir. Elde edilen verilerin analiz edilmesinde ilk olarak Gürcan (2003: 96- 98) tarafından oluşturulan haber sitelerinin içerik ve tasarımına yönelik değerlendirme formu esas alınmıştır.

\section{A B S T R A C T}

Internet journalism is the transmission of information to the audience by using various methods of journalism in written, visual or audial form. Due to these new opportunities, local media have had the opportunity to convey updates, problems and their values regarding their own local cultures to all around the world. Based on this determination, the importance of internet journalism in the new media world has been chosen as the subject of innovation practices of local newspapers in the city center of Bitlis. In the context of the method, the websites of Bitlis daily newspapers were examined with a weekly news and content analysis of the dates 09-15 November 2020. In analyzing the data obtained as a result of the content analysis, firstly, the evaluation form for the content and design of the news sites created by Gürcan (2003: 96-98) was taken as a basis.

\section{Giriș}

Bilgiye ulaşma ve elde edilen bilgiyi yayma konusu tarihin ilk günlerinden beri insanlık için önemli bir ihtiyaç olarak görülmüştür. Günümüz yeni medya düzeninde insanlığın söz konusu ihtiyacına cevap olarak görülen ve tüm dünyayı bir sarmaşı misali saran iletişim aracı, internettir. İnternet teknolojisi bilgisayar, bilgisayar ağları, sosyal medya, dijital medya vb. birçok kavramın ortaya çıkmasını sağlamıştır. İnternetin meydana getirdiği bu yeni düzen, bir medya aracı

\footnotetext{
* Sorumlu yazar/Corresponding author.

e-posta: acoskun@beu.edu.tr
} 
olarak gazeteleri de etkilemiştir. Geleneksel gazeteler, internet gazeteciliği olarak bilinen yenileşme sürecine girmişlerdir. İnternet gazeteciliği; gazetecilik mesleğinin temel ilke ve kurallarına bağlı kalınarak elde edilen bilginin yazılı, görsel ya da işitsel şekilde internet kullanılarak hedef kitleye ulaştırılmasıdır (Yurdigül ve Yüksel, 2012: 147148). Bu yeni gazetecilik türü, geleneksel olanı ile kıyaslandığında birçok avantajı ve dezavantajı beraberinde getirmektedir. Fakat teknolojik gelișmelerin her geçen gün dünyamıza hâkim olmaya devam ettiği 21 . yüzyıl iletişim ve bilgi çağında, internet gazeteciliğinin medya dünyası içindeki konumu ve etkinliği de artmaya devam etmektedir (Bulunmaz, 2011: 29). Bu yeni gazetecilik türü ile beraber, yaygın gazeteler daha çok okuyucuya ulaşma, dünyanın her yerinden okunabilme, haberlerini anında güncelleyebilme ve hızlıca yayın yapabilme imkânlarına sahip olmuşlardır. Aynı zamanda medya kuruluşlarının internet sayfaları da okuyucularla etkileşime girebilen, onların geri dönüşlerine olanak sağlayan platformlar hâline gelmiştir. Çoklu ortam olarak ifade edilen metin, ses ve videonun bir arada olduğu multimedya içerikleri de söz konusu sitelerde yer bulabilmektedir. Yine gazeteler kendilerine ait sosyal paylaşım siteleri üzerinden yüzlerce içerik paylaşabilmekte ve bu sitelerde hesapları olan okuyucuların haber, yorum, fotoğraf ve video ekleyebilmelerine olanak sağlamaktadır (Değirmencioğlu, 2011: 20).

Habercilik anlamında köklü değişimlerin yaşandığı bu süreçten yerel medya da nasibini almıştır. Öyle ki bu süreçte hem yerel gazeteler hem de yerel gazetede çalışan gazeteciler, yaşanan teknolojik gelişmelere ayak uydurmaya başlamışlardır. Fakat her yerel medyanın, internet ve internet gazeteciliğinin sahip olduğu olanakları kendi imkânları kadar kullanabildiklerini göz ardı etmemek gerekir (Çınar, 2019: 158). Bu gerçekliklerden hareketle bu makalede yerel gazetelerin, internet gazeteciliğine hem biçim hem de içerik olarak uyum sağlayıp sağlamadıkları araştırılmıştır. Makalenin örneklemi, Bitlis il merkezinde günlük olarak yayımlanan 5 gazetenin internet siteleridir. Bitlis il merkezinde günlük olarak Doğru Haber, Şark, Beşminare, Dideban ve Yeni Bitlis gazeteleri yayımlanmaktadır. Bu gazetelerin internet siteleri içerik analizi ile incelenmiştir. İçerik analizi sonucu elde edilen bulgular, Gürcan (2003: 9698) tarafindan oluşturulan haber sitelerinin içerik ve tasarımına yönelik değerlendirme formu esas alınarak yapılmıştır.

\section{Yerel Medya İșlevleri ve Önemi}

Tarihin ilk günlerinden beri insanlar, toplumsal yaşamda gerçekleşen olayları öğrenme ihtiyacı duymuşlardır. İnsanoğlunun bu öğrenme istenci, ticaretin yaygınlaşması, kamusal alanların oluşumu vb. etmenler uygarlığın gelişimine paralel olarak çağdaş basının ortaya çıkmasına vesile olmuştur. Yazıcı (2014: 9) çağdaş basın kuruluşlarının, yayınlandıkları ülkede hitap ettikleri alanın ve kitlelerin büyüklüğüne göre ulusal, bölgesel ve yerel olarak farklılaştıklarını dile getirmiştir. Buna göre ulusal basın, toplumdaki tüm bireylere ulaşmayı hedefleyen, kamuoyunu meşgul eden konulara ilgi gösteren ve bunlara ilişkin haberler yapan kuruluşlardır (Ural ve Hangül, 2019: 258). Bölgesel basın; bölgesinde olup biten politik, ekonomik, kültürel ve sanatsal etkinlikleri, haberler ve fotoğraflar ile okuyucusuna sunan basın kuruluşlarıdır. Bu basın kuruluşları, en az üç komșu il ya da bir coğrafi bölgeye hitap etmelidirler. Basın kuruluşlarından bir diğeri az önce de ifade edildiği gibi yerel basındır. Yerel basın Türk kamuoyunda 'yöresel basın', 'Anadolu basını' ya da 'taşra basını' olarak adlandırılmaktadır. Yerel basın hakkında birçok tanım yapılmıştır. Bunlardan bazıları şunlardır:

Yerel basın; İstanbul dışında yayın yapan, haberciliği ile yayınlandığ 1 yörenin sesini, sorunlarını yansitabilen, kendi mahallindeki sosyal, ekonomik, kültürel ve siyasi gelişmeleri, sağlıklı şekilde okurlarına aktarmayı amaç edilen kuruluşlar olarak tanımlanır (Erdoğan, 2006: 52).

Yerel medya, tek bir basın kuruluşu tarafından aynı isimle belirli bir yerleșim yerinde basılan ya da yayımlanan ve sadece o yerleşim biriminde dağıtılan veya izlenen gazete, radyo, dergi, televizyon yayınların tümünün genel adı olarak tanımlanabilir (Altun, 2005: 79).

Girgin (2001: 160) yerel basını, ulusal haberlerden farklı yalnızca yayınlandığ bölgede okunan yerel haberlerin ve konuların yer aldığı gazeteler ya da bir kasaba ve kentte yaşayan insanları ilgilendiren haberlerin yer aldı $\breve{g}_{1}$ gazete olarak tanımlar.

Kurtbaş vd. (2009: 20) yerel basını, belirli bir bölgede yayınlanan, yerel unsurları ve sorunları ortaya çıkarmayı hedefleyen kuruluşlar olarak tanımlamışlardır.

Yerel medya; her türlü olayı kendi bölgesinin, ilinin ve ilçesinin değer yargılarına, beklentilerine, sorunlarına ve umutlarına göre ele alıp bu bakıș açısıyla sunum yapar. Yerel basının en önemli işlevi; dünyada gelişmekte olan olay ve olguların, hitap edilen halk açısından değerlendirilmesi, içerik, sayfa tasarımı gibi temel unsurlar hazırlanırken de yerel farklılıkların dikkate alınması, yani dünyaya yerel pencereden bakılması ve öncelikli olarak yerel kamuoyunun bilgi, haber ve eğlence gibi ihtiyaçlarının karşılanmasıdır (Kösedağ, 2016: 1590).

Nihayetinde yerel basının özelliklerini aşağıdaki gibi siralayabiliriz:

1. Yerel basın, sınırları belli bir yörede faaliyet yapar.

2. Yerel basın, gazetecilik mesleğinin görevlerini ve işlevlerini söz konusu yörede ifşa eder.

3. Yerel basın, yöre halkının gözü, kulağı, dili olurken aynı zamanda yerel kamuoyunun oluşmasına katkı sağlar.

4. Yerel basın, yönetenleri denetleme görevini üstlenir.

5. Yerel basın, yaptığı haberler vasitasıyla bölgede yaşayan insanların yerel yönetimlerle s1kı bağlar kurmasını sağlar.

6. Yerel basın, yerel halkın politik eğilimlerinde ve siyasal hayata katılımlarından önemli roller üstlenir.

Yerel basın, birçok açıdan yaptığı haberler ve yorumlarla yerel yöneticilerin dikkatlerini çekmeye çalışır. Bu sayede yöre halkı ile yerel yöneticiler arasında köprü görevi görerek insanlara yaşanan yer düşüncesini kazandırır. Öyle ki yerel halk, yerel basın organlarından aldığı bilgiler 1şığında kamuoyu oluşturur, katılımcı demokrasinin gelişmesine katkı sağlar. Bu açıdan yerel basının yaptığı haberlerin çevre ile ilişkili olmasının ötesinde adil, objektif ve dengeli olması gerektiği aşikârdır. Yerel basın kuruluşları politik, sosyal, 
ekonomik konuların en ince ayrıntılarına indiğinden dolayı bulundukları yerlerde büyük etkilere yol açarlar. Yine baskı sayıları az olmasına rağmen yerel gazeteler basıldığı sayıdan çok daha fazla sayıda okunabilir, o yörede ilgi odağ 1 olabilirler (Kayacan, 1996: 82). Yerel basın, yaygın basının temel görevlerinden eğitim işlevini toplumsal kimliği ile sağlamaya çalışır. Yerel basının en önemli işlevi ise ulusal iradenin doğru ve amaca uygun yansıması için gerekli demokrasi kültürünün yerleşmesine olan katkısıdır (Gezgin 2007: 177- 178).

Yerel medyanın ayrıca yerel yönetimler ve yerinden yönetim birimlerinin denetimini sağlaması açısından da önemli görevleri vardır. Yine yayın yaptığı bölge haklının sorunlarının ve taleplerinin kamuoyunda tartışılması hususu da yerel medyanın önemli işlevlerindendir. Bunlara ek olarak yerel medyanın yayımladığı haberler, fotoğraflar, ele aldığı sorunlar yörede yaşayan halkın biz bilincini oluşturması açısından önemlidir. Yöre halkı bu sayede yaşadığ1 yerin bir parçası olduğunu kabul ederek ortak yaşam alanlarının iyileştirilmesi için mücadele ederler (Karaduman, 2017: 287). Bu hususta belirtmek gerekir ki medya kuruluşları kapitalist ekonomik sistemde ancak kapitalizmin gerektirdiği türden örgütlenmeyi başarırlar. Dolayısı ile ticari işletmeler olarak faaliyetlerinde devam eden medya kuruluşlarının her türlü üretim (Haber, TV programı, sinema filmi vb.) meta olarak değer kazanmaktadır. Bu ürünler hem kültürel hem de ekonomik değerleri yansıtmaktadırlar (Öztürk, 2008: 132). Sonuçta kâr maksimizasyonu üzerine kurulan bir ulusal, bölgesel ya da yerel medya yapılanmasında, dönemin siyasi ve toplumsal koşulları doğrultusunda (Dağtaş ve Aydın, 2017: 24) halkın sorunları ve talepleri göz ardı edilebilmektedir.

\section{Enformasyonun Dijitalleşmesi ve İnternet Gazeteciliği}

İletişim tarihi, genellikle arka arkaya bir dizi medya aracının evrimsel açıdan gelişme gösterdiği süreçtir. Bu uzun süreçte üç önemli dönüm noktasının olduğu görülmektedir. Bunlar yazının bulunması, matbaanın icat edilmesi ve elektrikelektronik devrimdir (Öztürk, 2017: 317). Her birinin önemi azımsanmayacak derecede büyük olan bu dönemlerin günümüze en yakın olanı elektrik-elektronik devrimdir.

Elektrik-elektronik devrim ile birlikte dünya yeni ve eşi benzeri görülmemiş bir küresel gerçeklik buhranına kapılmıştır. Özellikle hareketli film, radyo, televizyon, telefon ve internet gibi iletişim konusundaki buluşlar insanoğlunun tek bir gezegen toplumu hâline gelmesini sağlamıştır (Güçdemir, 2003: 372). Yeni teknolojiler ve özellikle internet, kitle iletişim araçlarının da değişim ve dönüşüm geçirmesine vesile olmuştur. Yerel ve geniş alan ağlarının birbirlerine bağlanması ile oluşan, ağların ağı olarak tanımlanan internet, ilk olarak Amerika Birleşik Devletleri'nde (ABD) ortaya çıkmıştır. Daha sonra birçok ülkede devlet kurumlarının yanı sira ticarette, sanayide, reklamcılıkta ve gazetecilikte de yaşamı etkisi altına almayı başarmıştır (Gürcan, 1998: 144- 145). İnternetin kısa sayılabilecek sürede yaşamımızın her alanını sarmasına ve bilgisayar teknolojilerinin gelişmesine paralel olarak internet gazeteleri de yayınlanmaya başlanmıştır. İnternet gazeteciliği en yalın tabirle gazeteciliğin ilke ve kurallarının elektronik ortamlarda icra edilmesi olarak tanımlanabilir. Bu gazeteler içeriğin oluşumu ve okuyucuya sunumu noktasında diğer geleneksel gazetecilik (radyo, televizyon, yazılı basın, fikir gazeteciliği vb.) tanımlarından farklı anlamlar ifade etmektedirler. İnternet gazetelerinin günümüz dünyasında binlerce örneği vardır. Bu gazeteler, önceleri belirli bölgede yerel network ağları ile hizmet verirken, günümüzde internet sayesinde geniş kitlelere ulaşabilme imkânına erişmişlerdir (Mumay, 2003: 56).

İnternet gazetelerinin ilk biçimi teletekstir. Teleteks, veri iletişimine uyumlu televizyon setinde görüntülenmek üzere metin ve grafiklerin interaktif olmadığ 1 bir iletim sistemine verilen addır. 1970 yılında İngiltere'de icat edilmiştir. 1971 yılında British Broadcasting Corporation (BBC) tarafindan patenti alınarak ilk kez 1973 'te Londra'da tanıtılmıştır. O dönemde BBC tarafından see factes cümlesinden oluşturulan Ceefaz şekliyle adlandırılmıştır. Ülkemizde ilk olarak 1990 yılında Telegün adıyla TRT tarafından kullanılmıştır. Teleteks kullanıcıları ekonomi, spor, hava ve yol durumu hakkında bilgilere erişebilmektedirler (Kılıç, 2015: 81). İnternet gazeteciliğinin türleri, ilk örneklerinden sonra, 1990'lı yılların ikinci yarısından itibaren sayısal olarak belirgin bir şekilde artış göstermiştir. $\mathrm{Bu}$ artışa hem geleneksel medya kuruluşlarının internet gazeteciliğine yönelik ilgilerinin artması hem de medya kuruluşlarından bağımsız kişilerin internette gazetecilik içeriği sunmak amacıyla yaptığı yatırımlar kaynak gösterilebilir (Aydoğan, 2012: 2). Türkiye'de doğrudan internet üzerinden yayınlanmaya başlanan ilk gazete $\mathrm{Xn}$ gazetesidir. Bu gazete 25 Ocak 1996 y1lında http//www.planet.com.tr adresinden internete giriş yapmıştır. Xn sanal gazetesi, geleneksel gazetelerin köşe yazarlarının o günkü basılı gazetelerinden yazdıkları yazıları internete yükleyerek işe başlamıştır. Sonrasında haberlerin günlük değil, anlık olarak ayrıntılarıyla birlikte verilmesi amacını gütmüştür. Tarihler 17 Aralık 1997 yılını gösterdiğinde basılı bir gazetenin yansıması olmayan SuperOnline yayın hayatına başlamıştır. Sonra sirasıyla 1995 yılında Aktüel dergisi ve 1996 Milliyet, Sabah, Hürriyet ve Akşam gazeteleri internet gazeteciliğine giriş yapmışlardır (Gürcan, 1998: 146). Ülkemizde internet gazetelerinin önemli bir bölümünün geleneksel medya kuruluşlarının faaliyetlerini internet siteleri aracılığıyla yürütme çabasını güttüklerini söyleyebiliriz. Bu hâliyle geleneksel medya gruplarının internet medyası ortamında var olmayı ya da tutunmayı denedikleri görülmektedir. Bunun yanı sıra internet medyasında kendisine yer bulan haberlerin geleneksel medya kuruluşları tarafından üretildiği göz ardı edilemez. Bu noktada haber üretimi alanındaki sorunların internet ortamında da yaşanması doğaldır (Çevikel, 2004: 150).

İnternet gazeteleri basılı gazetelerin internet sayfaları ve haber portalları olmak üzere ikiye ayrılabilir. Her ikisi de özü itibariyle aynı işi yapmakla beraber haberin temel kaynağı ve haberin üretim aşamasında farklılıklar bulunmaktadır. Örneğin basılı gazetelerin internet sayfaları, gazetelerin internet üzerinden hiçbir değişiklik yapılmadan verilmesidir. Buna karşın sadece internet sayfasında yazan yazarlar da bulunmaktadir (Bulunmaz, 2011: 32). İnternet gazetelerinin en dikkat çekici tarafi okuyucunun okuduğu haberle ilgili duygu ve düşüncelerini dile getirebilmesi olarak belirtilebilir. Yani internet gazeteleri okuyucu ile karşılıklı iletişime girmesi açısından geleneksel gazetelerden ayrilmaktadır. İnternet gazetelerinde yorum yapabilmek, okuyucuları katılımcı ve etkileşimci hâle getirmektedir. Bu 
da okuyucunun haberin kendisine yorum ekleyebilmesine ve haber içeriğini değerlendirilerek eleştiri nesnesi yapılabilmesine olanak sağlamaktadır (Korkmaz, 2009: 7). Böylelikle hem gazeteciler hem de okuyucular çevrim içi ortamlarda birbirleri ile iletişim kurma imkânı edinmişlerdir. $\mathrm{Bu}$ yolla gazeteciler, okurları ile dolaysız iletişime girerek haber kaynaklarına daha hızlı ulaşabilmektedir. Aynı şekilde okurların beklenti ve isteklerini tespit ederek hızlıca cevap verebilme ve haberlerde yer alan gerçeklerle ilgili yapılan hataları düzeltebilme imkânı elde etmişlerdir. Okurlar açısından da gazeteciler ile dolaysız olarak iletişim kurulabilmesi onların kendilerini gazetelerin bir parçası olarak görmelerini arttırmıştır (Aktaş, 207: 38). İnternet gazeteciliğinin okurlara sunduğu olanakları ve geleneksel gazetecilik türlerinden farkları şu şekilde sıralanabilir:

1. Haberin hızlı verilebilmesi ve sürekli olarak güncellenebilmesi.

2. Okurun yayınlanan habere dilediği zaman ulaşabilmesi.

3. Haberlerde ses-grafik-görüntü dosyalarının kullanılmasına imkân sağlaması.

4. Arşiv haberlerine ulaşılabilme ve istenilen haberin kayit altına alınabilmesi.

5. Haberci ile okurun interaktif etkileşimine olanaklı k1lmasi.

6. Haberle ilgili arka plan bilgilerine kolaylıkla ulaşılabilmesi.

7. Farklı medya türlerinde kendine yer bulamayan haberlerin bu mecralarda yer bulabilmesi (Karaduman, 2005: 147).

Görüldüğü üzere internet gazeteleri hem gazetecilere hem de okuyuculara birçok imkân sunmaktadır. $\mathrm{Bu}$ imkânlar sayesinde internet gazeteleri geleneksel gazetecilikten daha avantajlı konumda yer almaktadır. Dolayısıyla günümüz insanlarının haber alma ihtiyaçlarını giderme noktasında çevrim içi kaynaklara ya da internet gazetelerine yönelmesi gayet doğaldır.

\section{Araştırmanın Amacı ve Önemi}

İnternet gazeteciliğinin giderek geliştiği ve yaygınlaştığı bir ortamda yerel gazetelerin bu duruma uyum sağlayıp sağlamadığı konusu önem arz etmektedir. $\mathrm{Bu}$ tespitten hareketle internet gazeteciliğinin her geçen gün önem kazandığı yeni medya dünyasında, Bitlis il merkezindeki yerel gazetelerin yenileşme pratiklerinin değerlendirilmesi önem arz etmektedir. Literatürde Bitlis yerel medyasına yönelik yeterli çalışmaya rastlanmamış olması bir eksiklik olarak değerlendirilmiştir. Bu durum çalışmanın önemini oluşturmaktadır. Söz konusu önemden hareketle yerel gazetelerin internet ortamındaki görünümleri inceleme konusu olarak seçilmiştir. Çalışmada temel amaç, Bitlis il merkezinde günlük olarak yayımlanan gazetelerin internet ortamındaki görünümlerinin biçim ve içerik açısından betimlenmesidir. $\mathrm{Bu}$ amaç kapsamında gazetelerin internet ortamındaki görünümleri; yerel gazetelerin web siteleri; siteye ulaşılabilirlik, genel görünüş, kullanım kolaylığı, içerik (yetkinlik, doğruluk, yansızlık, kapsam, güncellik, haber yazım kuralları ve dil kullanımı), teknik özellikler, kurumsal bilgiler, etkileşimlilik bakımından incelenmiştir.

\section{5. Örneklem}

Araştırmanın örneklemini Bitlis il merkezinde günlük yayımlanan yerel gazetelerin web siteleri oluşturmaktadır. Bitlis Valiliği ve Basın İlan Kurumu'ndan alınan güncel bilgilere göre, Bitlis il merkezinde günlük olarak 5 gazete yayımlanmaktadır. Bunlar; Doğu Haber, Şark, Beşminare, Dideban ve Yeni Bitlis gazeteleridir. $\mathrm{Bu}$ gazetelerin tümünün de internet sayfaları bulunmaktadır. Gazeteler hakkında ayrıntılı bilgiler elde etmek amacıyla, gazete sahipleri/çalışanları ile yapılan görüşmelerde ortak hususlar tespit edilmiştir. Örneğin ilgili yayın organlarının hiçbirinin genel yayın politikası belirtilmemiştir. Günlük ortalama tiraj sayısında (250) ve internette erişim oranlarında (1500) ise benzerlikler görülmüştür. Ekonomik yapıları açısından tüm gazetelerin Basın İlan Kurumu sayesinde faaliyetlerine devam ettikleri, kamuoyu oluşturma konusunda da tüm gazetelerin alt yapı, eleman eksikliği, maddi sıkıntılar vb. nedenlerden kaynaklı olarak yetersiz kaldığı gazete sahipleri ve çalışanları tarafından belirtilmiştir. Aynı kişiler Doğru Haber ile Şark ve Beş Minare ile Dideban gazetelerinin sahiplerinin aynı, Yeni Bitlis gazetesinin ise farklı olduğunu da açıklamışlardır.

\section{Yöntem}

Yöntem bağlamında, Bitlis il merkezinde günlük yayımlanan ilgili gazetelerinin internet siteleri 09-15 Kasım 2020 tarihleri arasında bir haftalık sürede, içerik analizi ile incelenmiştir. İçerik analizi; “a. işaretlerin sınıflanması, b. bu işaretlerin hangi yargıları içerdiğini ortaya koymak için, c. açıkça formüle edilmiş kurallar ışığında, d. araştırmacının ortaya koyduğu yargıların bilimsel rapor olarak değerlendirilmesini sağlar" (Janis 1949: 425'ten akt. Koçak ve Arun, 2006: 22).

İçerik analizi neticesinde elde edilen verilerin analiz edilmesinde ilk olarak Gürcan (2003: 96- 98) tarafindan oluşturulan haber sitelerinin içerik ve tasarımına yönelik değerlendirme formu esas alınmıştır. Form ilk olarak siteye ulaşılabilirlik, genel görünüş, kullanım kolaylığı, içerik, teknik özellikler, kurumsal bilgiler ve genel değerlendirme ve yorum olmak üzere yedi temel sinıflandırmadan oluşmaktaydı. Bu form ilerleyen süreçte Gürcan ve Bayram (2005) tarafından genişletilmiştir. Söz konusu değerlendirme formunun son şeklinde, geri kalan başlıklar aynı kalmakla beraber genel değerlendirme ve yorum başlığı etkileşimlilik olarak değiştirilmiştir.

\section{Bulgular ve Yorum}

Bitlis il merkezinde günlük olarak yayımlanan yerel gazetelerin web siteleri Tablo 1'de görüldüğü gibi "Değerlendirme Kriterleri Formu" dikkate alınarak incelenmiştir. İncelenme neticesinde bu web sitelerine ilişkin özellikler tek tek değerler halinde yansıtılmaya çalışılmıştır. 
Tablo 1: Bitlis Yerel Gazetelerinin İnternetteki Ana Sayfalarının Karşılaştırmalı Analizi

\section{SITTEYE ULAŞILABILLIRLIKK}

İşaretler: var, evet: +

Doğru Haber

Şark

Beşminare

Dideban

Yeni Bitlis

yok, hayır: $x$

\begin{tabular}{lccccc}
\hline Siteye Erişim Rahatlı̆̆1 & + & + & + & + & 1 \\
\hline Sitenin Yüklenme Süresi (saniye) & 5 & 1 & 1 & $\times$ & $\times$ \\
\hline Site Haritası & $\times$ & $\times$ & $\times$ & $\times$
\end{tabular}

Siteye ulaşlabilirlik, web siteleri için önem arz eden faktörlerden biridir. Web sitelerinin ulaşılabilir olması kadar yüklenme süresinin de hızlı olması gerekmektedir. Web sitesinin hızlı olarak kabul edilmesi için sayfaların ortalama on beş saniyeden önce yüklenmesi gerekmektedir (Bayram ve Yaylı, 2009: 353). Formun birinci bölümünde "sitelere ulaşılabilirlik" kriterleri incelenirken Bitlis Eren Üniversitesi Güroymak Meslek Yüksekokulu'nun internet altyapısı kullanılmıştır. Buna göre; Doğru Haber, Şark, Beşminare, Dideban ve Yeni Bitlis gazetelerinin sitelerine 09-15 Kasım
2020 tarihleri arasında farklı zamanlarda erişim sağlanmıştır. Elde edilen bulgular ortalama değerler hesaplanarak girilmiştir. Tablodan anlaşıldığı üzere erişim rahatlığı açısından tüm siteler kullanıcılara kolaylıklar sağlamaktadır. Buna karşın sitelerin yüklenme süreleri farklılıklar göstermektedir. Doğru Haber sitesinin diğer sitelere oranla yüklenme süresi bakımından daha yavaş olduğu açıktır. Bu durum bilgiye çabuk ulaşma alışkanlığı edinmiş olan internet kullanıcıları için bir dezavantajdır. Site haritasını ise hiçbir gazetenin kullanmadığı görülmektedir.

\begin{tabular}{|c|c|c|c|c|c|}
\hline & & GENF & ÖRÜNÜŞ & & \\
\hline $\begin{array}{r}\text { İşaretler: var, evet: + } \\
\text { yok, hayır: } x\end{array}$ & $\begin{array}{l}\text { Doğru } \\
\text { Haber }\end{array}$ & Şark & Beşminare & Dideban & Yeni Bitlis \\
\hline Ana sayfanın genel görünüşü & + & + & + & + & + \\
\hline Ana sayfanın kullanım rahatlığ & + & $x$ & + & + & + \\
\hline Sayfalarda renk kullanımı & $x$ & $x$ & $x$ & $x$ & + \\
\hline Zemin rengi & Beyaz & Beyaz & Beyaz & Beyaz & Beyaz \\
\hline Sayfalar arası uyum & + & + & + & + & + \\
\hline Türkçe karakter desteği & + & + & + & + & + \\
\hline Sayfa uzunluğu & + & + & + & + & + \\
\hline Sayfa kenar boşlukları & + & + & + & + & + \\
\hline Haberlerde fotoğraf kullanımı & + & + & + & + & + \\
\hline Sayfadaki butonların işlerliği & + & + & + & + & + \\
\hline Mesaj panosu/ Forum/Anket & + & + & $x$ & $\times$ & $x$ \\
\hline Sayfalarda İkon/Banner yoğunluğu & $x$ & $x$ & $\times$ & $x$ & $x$ \\
\hline Ziyaretçi sayacı & $\times$ & $x$ & $x$ & $x$ & $\times$ \\
\hline
\end{tabular}

Formun ikinci bölümünü "genel görünüş" kriterleri oluşturmaktadır. Sitelerin hedef kitlenin beğenisini kazanmaya yönelik, sitelerdeki sayfaların rahat okunabilirliği, sayfalardaki butonların işlerliği, Türkçe karakter desteğinin kullanılması, sayfalarda renk kullanılması gibi estetik figürleri ön plana çıkarmaları önemlidir (Gürcan, 2003: 92). Siteler bu yönüyle değerlendirildiğinde ana sayfanın genel görünümü, sayfalar arası uyum, Türkçe karakter desteği, sayfa uzunluğu, sayfa kenar boşluğu, haberlerde fotoğraf kullanımı, sayfalardaki butonların işlerliği gibi kriterler bakımdan olumlu sonuçlar elde edilmiştir. Zemin rengi kriterinde tüm sitelerin beyaz zemini tercih ettikleri, ziyaretçi sayacı ve sayfalarda renk kullanımı kriterlerini ise kullanmadıkları görülmüştür. Ana sayfanın kullanım rahatlı̆̆ı özelliğinde sadece Şark gazetesinin sitesinde sorunlarla karşılaşılmıştır. Buna karşın mesaj panosu/forum/anket özelliğinin Doğru Haber ve Şark gazetesi sitelerinde kullanıldığı, Beşminare, Dideman ve Yeni Bitlis gazetesi sitelerinde ise kullanılmadığ 
görülmüştür. Son olarak sayfalarda ikon/banner yoğunluğu tüm sitelerde kullanılmamıştır.

\section{KULLANIM KOLAYLIĞI}

\begin{tabular}{|c|c|c|c|c|c|}
\hline $\begin{array}{r}\text { İşaretler: var, evet: + } \\
\text { yok, hayır: } x\end{array}$ & $\begin{array}{l}\text { Doğru } \\
\text { Haber }\end{array}$ & Şark & Beşminare & Dideban & Yeni Bitlis \\
\hline Font kullanımı ve rahat okunabilirlik & + & + & + & + & + \\
\hline Ana sayfadan haberlere ulaşmada sıkıntı var mı? & $\times$ & + & $x$ & $\times$ & $x$ \\
\hline Sayfalar arası geçiş-bağlantı & + & + & + & + & + \\
\hline Site içi arama & + & + & + & + & + \\
\hline Arşiv ve arşive ulaşma imkânı & $\times$ & $x$ & $\times$ & $x$ & $x$ \\
\hline Kelime, tarih, haber olarak arama yapılabiliyor mu? & + & + & + & + & + \\
\hline Sayfalarda çıktı alma imkânı & $\times$ & $x$ & $x$ & $\times$ & + \\
\hline Dil seçim olanağ1 & $x$ & $x$ & $x$ & $x$ & $x$ \\
\hline
\end{tabular}

Bir web sitesinin gerçek özelliği yazıların, grafiklerin ve animasyonların kullanımıyla hedef kitle arasında iletişim kurmaya imkân vermesi ve bağlantılar, aramalar ile de yardımcı olmasıdır. Tüm bu faktörler web sitesi tasarımı ve onun kullanım kolaylığı ile ilişkilidir (Bayram ve Yaylı, 2009: 353). Haber sitelerinde kullanım kolaylığının olmasının temel ilkesi müşteri merkezli desendir. Müşteri merkezli desen, bir web sitesi hazırlanırken ilk olarak göz önünde tutulması gereklidir. Çünkü kullanıcıların beklentileri ile sayfanın kolayca okunması, formların ve linklerin kaybolmaması gibi hususlar müşteri merkezli desenle ilgilidir.
Dolayısıyla web site ve sayfalarının hazırlanmasında sadelik her zaman göz önünde tutulmalıdır (Ergün ve Ergün, 2008: 7). Formun üçüncü bölümünde "kullanım kolaylığı" kriterleri incelenmiştir. Font kullanımı ve rahat okunabilirlik, sayfalar arası geçiş-bağlantı, site içi arama ve kelime, tarih, haber olarak arama kriterlerini tüm siteler kullanmaktadırlar. Buna karşın beş sitenin de arşiv ve arşive ulaşma imkânı, dil seçimi özelliğini kullanmadıkları görülmüştür. Sayfalarda çıktı alma imkânının ise sadece Yeni Bitlis gazetesi sitesi tarafından sağlandığı tespit edilmiştir. Son olarak sadece Şark gazetesi sitesinde ana sayfadan haberlere ulaşılabilmiştir.

\section{4. İÇERIK}

\section{A. YETKİNLIKK}

İşaretler: var, evet: +

Doğru Haber Şar

yok, hayır: $x$

\begin{tabular}{|c|c|c|c|c|c|}
\hline Sayfanın içeriğinden sorumlu olan kişi belli mi? & + & + & $x$ & $x$ & + \\
\hline $\begin{array}{l}\text { Haber sitesinin amaçlarının, yayın politikasının } \\
\text { tanımlandığı bir sayfa var mı? }\end{array}$ & $\times$ & $x$ & $x$ & $x$ & $x$ \\
\hline Sayfalar amaç/yayın politikasına uygun mu? & $x$ & $x$ & $x$ & $x$ & $x$ \\
\hline $\begin{array}{l}\text { Haber sitesinin meşruluğunu (gerek ticari gerekse } \\
\text { hukuki) gösterecek ibare mevcut mu? (posta adresi } \\
\text { ve telefon gibi) }\end{array}$ & + & $x$ & $x$ & $x$ & + \\
\hline $\begin{array}{l}\text { Haber sitesinin başka bir yayım şekli var mı? } \\
\text { (gazete, dergi, radyo, TV gibi) }\end{array}$ & + & + & + & + & + \\
\hline Gündem anlık takip ediliyor mu? & + & + & + & + & + \\
\hline Haber yoğunluğu (sayısal adet) & 15 & 7 & 15 & 15 & 9 \\
\hline Haber özetlerini tek sayfada görebilme & + & $x$ & + & + & + \\
\hline Haberin türlerine göre gruplandırılması & + & + & + & + & + \\
\hline Sitede kișisel yazıların yazarları belirtilmiș mi? & $x$ & $x$ & $x$ & $x$ & $\times$ \\
\hline
\end{tabular}


Formun dördüncü bölümünde “içerik" kriterlerinden "yetkinlik" kriterine yer verilmiştir. İçerik, web sitelerinin kullanıcılar açısından bir diğer önemli kriteridir. İçerik her şeyden önce işlevsel bir yapıya sahip olmalıdır. Web sitesinin içerik açısından zenginleştirilmiş olması için yetkinlik, doğruluk, yansızlık, kapsam, güncellik, haber yazım kuralları bakımından tamamlanmış olması gerekmektedir. Çünkü pek çok kullanıcı sitenin içeriğiyle veya eğlendirici olmasıyla daha çok ilgilenmektedir. Bu anlamda sitenin içerik anlamında tamamlanmış olması kullanıcıları etkilemesi bakımından önemlidir (Dikener, 2011: 158). Site içerikleri A. Yetkinlik, B. Doğruluk, C. Yansızlık, D. Kapsam, E. Güncellik, F. Haber Yazım kuralları ve dil kullanımı başlıklarından oluşmaktadır. Yetkinlik başlığında elde edilen bulgular yukarıda gösterilmiştir. Buna göre; haber sitesinin başka bir yayım şekli var mı (gazete, dergi, radyo, TV gibi), gündem anlık takip ediliyor mu, haberin türlerine göre gruplandırılması var mı gibi başlıklarda beş site de bu kriterleri sağlamaktadır. Haber sitesinin amaçlarının, yayın politikasının tanımlandığı bir sayfa var mı, sitede kişisel yazıların yazarları belirtilmiş mi kriterleri tüm sitelerde bulunmamaktadır. Doğu Haber, Şark ve Yeni Bitlis gazetesi sitelerinde sayfanın içeriğinden sorumlu olan kişiler belli iken, Beşminare ve Dideman gazetesi sitelerinde bu kişiler belli değildir. Haber özetlerini tek sayfada görebilmenin sadece Şark gazetesi sitesinde yetersiz olduğu, haber sitesinin meşruluğunu (gerek ticari gerekse hukuki) gösterecek ibare mevcut mu (posta adresi ve telefon gibi) kriterinin ise Doğru Haber ve Yeni Bitlis gazetesi sitelerinde yeterli olduğu görülmüştür. Haber yoğunluğunda Şark gazetesi sitesinin diğerlerine göre eksik haberler gösterdiği tespit edilmiştir. Son olarak sayfalar amaç/yayın politikasına uygun mu kriteri gazetelerin amaç/yayın politikaları bilinmediğinden değerlendirilmeye alınmamıştır.

\begin{tabular}{|c|c|c|c|c|c|}
\hline \multicolumn{6}{|c|}{ 4. İÇERİK } \\
\hline & B. DOĞRUL & & & & \\
\hline $\begin{array}{r}\text { İşaretler: var, evet: }+ \\
\text { yok, hayır: } x\end{array}$ & Doğru Haber & Şark & Beşminare & Dideban & Yeni Bitlis \\
\hline Haber kaynaklarının belirtilmesi & $\times$ & $x$ & $\times$ & $\times$ & $\times$ \\
\hline Haberlerde birincil kaynaklardan mı alınıyor? & $\times$ & $\times$ & $\times$ & $\times$ & $\times$ \\
\hline Haber başka kaynaklardan doğrulanabilir özellikte & & & & & \\
\hline mi? & + & + & + & + & + \\
\hline Haberlerin editöryel işlemden geçmiş izlenimi var mı? & + & + & + & + & + \\
\hline $\begin{array}{l}\text { Haberler gramer, hece ve yazım hatalarından } \\
\text { arındırılmış mı? }\end{array}$ & + & + & + & + & + \\
\hline Yazarların uzmanlığı ve konuya yetkinliği & + & + & + & + & + \\
\hline
\end{tabular}

İçerik kriterinin ikinci başlığı doğruluktur. İnternet, isteyen herkesin denetimsiz bir şekilde bilgi yayınlamasına olanak sağlayan bir teknolojidir. Bu teknoloji kullanılarak bilgi yaymak hem basit hem de tehlikelidir. Çünkü "internetten sağlanan bilgilerin doğrulanabilmesi ve aslına uygun olup olmadı̆̆ının araştırılması (authentication) elektronik ortamdaki bilgilerin aradan geçen zaman içinde güncellenmesi ya da transfer anında kolayca değiştirilebilmesi (yanlışlıkla ya da kötü niyetle) veri bütünlügü ve veri güvenliği ile ilgili sorunları da beraberinde getirmektedir" (Esgin vd., 2011: 2). Bu yüzden doğruluk kriteri, sitede yer alan haberlerin hatasız ve güvenilir olmasını gerektirmektedir. Siteler doğruluk açısından incelendiğinde haber kaynaklarını belirtmediklerinden haberlerin birincil kaynaklardan alındığına dair bilgiye ulaşılmamıştır. Tüm sitelerin haberlerinin başka kaynaklardan doğrulanabilecek nitelikte olduğu, haberlerin editöryal işlemden geçtiği, gramer, hece ve yazım hatalarına rastlanmamıştır.

\begin{tabular}{|c|c|c|c|c|c|}
\hline \multicolumn{6}{|c|}{ 4. İÇERİK } \\
\hline & C. YANSIZI & & & & \\
\hline $\begin{array}{r}\text { İşaretler: var, evet: + } \\
\text { yok, hayır: } x\end{array}$ & Doğru Haber & Şark & Beşminare & Dideban & Yeni Bitlis \\
\hline Ana sayfada reklam kullanım yoğunluğu (sayısal adet) & $\times$ & $\times$ & $x$ & $\times$ & $x$ \\
\hline $\begin{array}{l}\text { Haberin içeriği, reklam ve yorum yazılarından } \\
\text { kolaylıkla ayrılabiliyor mu? }\end{array}$ & $\times$ & $x$ & $x$ & $\times$ & $x$ \\
\hline Yorum yazıları açık olarak gösterilmiş mi? & $x$ & $x$ & $\times$ & $x$ & $x$ \\
\hline
\end{tabular}


İçerik kriterinin üçüncü başlığı yansızlıktır. Yansızlık gazeteciliğin önemli kavramlarından biridir. Bu kavram basın tarihi boyunca gerçeğe ulaşmanın bir yolu olarak bilinmiş, gazetecilik mesleğinin ise en yüksek ahlaki amacı olarak kabul görmüştür. Kitlelerin ancak tarafsızlık ilkesinin benimsemiş gazeteciler tarafından doğru bilgilendirdiği kabul görmektedir. Ancak, birey olarak gazetecinin yansızlık konusunda gösterdiği azmin, okuyucuların gerçekleri öğrenmesine her zaman yetip yetmediği de sorgu konusudur (Atabek, 1994: 23- 24). Bu gerçeklik değişmez olanın sesi, habercinin kendisidir. Bun karşın haber metinlerinin, ileri sürüldüğü gibi yoruma yer vermeyen, yansız ve duygusallıktan uzak olduğu söylenemez. Nitekim internetteki haberlerin büyük çoğunluğu, toplumu kışkırtıcı içerikler yoluyla hâkim görüşü tekrar tekrar farklı biçimlerde üretmektedir. Bu anlamda, ölçülebilir sayısal verilere haber metinlerinde benimsenen nesnellik örüntüsünü desteklemek amacıyla başvurulduğu söylenebilir (Koç, 2017: 125).

Bu doğrultuda siteler yansızlık açısından incelendiğinde tüm sitelerin ana sayfa reklam kullanım yoğunluğu, haber içeriklerinin reklam ve yorum yazılarından ayrımı ve yorum yazılarına yer vermedikleri görülmektedir. Buna karşın yansızlık kriterinin benimsenmiş olması o sitenin yansızlığı konusunda kesin bir argüman oluşturmamaktadır. Çünkü sitelerin tamamının yansızlık ilkesine uygun olarak haber yaptığını söyleyebilmemiz için tüm haberlerin incelenmesi gereklidir.

\begin{tabular}{|c|c|c|c|c|c|}
\hline \multicolumn{6}{|c|}{ 4. İÇERİK } \\
\hline & D. KAPSAM & & & & \\
\hline $\begin{array}{r}\text { İşaretler: var, evet: + } \\
\text { yok, hayır: x }\end{array}$ & Doğru Haber & Şark & Beşminare & Dideban & Yeni Bitlis \\
\hline Haber kaynaklarına ilişkin sayfalara bağlantı var mı? & $x$ & $\times$ & $\times$ & $\times$ & $\times$ \\
\hline Site, basılı gazetenin versiyonu ise benzeşik mi ayrı mı? & + & + & + & + & + \\
\hline Özel-araştırma dosyalarına yer verme & $x$ & $\times$ & $x$ & $\times$ & $x$ \\
\hline Haber dışı konulara yer verme & + & + & + & + & + \\
\hline Anket, test vb. okur katılımına yönelik olanaklar & $x$ & $\times$ & $x$ & $x$ & $x$ \\
\hline Hobi, oyun, e-ticaret vb. bölümler var mı? & $x$ & $x$ & $x$ & $x$ & $x$ \\
\hline
\end{tabular}

İçerik kriterinin dördüncü başlığı kapsamdır. İletişim doğası gereği sürekli bir hareket ve dinamizm gerektirmektedir. Bu yüzden iletişim olgusu, kişiler ve toplumlar arasında haberlerin duyu, düşünce ya da fikirlerin iki yönlü değişim süresini kapsamaktadır. Haliyle iletişim kapsamını yazılı, sesli veya görsel unsurların toplanıp dağıtıma sokulması olarak bilinmektedir (Banar, 2006: 126). Siteler kapsam başlığına göre değerlendirildiğinde büyük eksikler tespit edilmiştir. Buna göre sitelerin hiçbirinde haber kaynağı bağlantısı, özel araştırma dosyalarına yer verme, okur katılımına yönelik test, anket ve hobi, oyun, e-ticaret vb. bölümleri kullanılmamaktadır. Sitelerin tümünün ise sitegazete benzeşmesi ve haber dışı konulara yer verdikleri görülmektedir.

\section{4. İÇERIK}

E. GÜNCELLIK

\begin{tabular}{lccccc}
\hline $\begin{array}{l}\text { İşaretler: var, evet: }+ \\
\text { yok, hayır: } \mathbf{x}\end{array}$ & Doğru Haber & Şark & Beşminare & Dideban & Yeni Bitlis \\
\hline Haberler ne kadar süreyle güncelleniyor? & 1 günlük & 2 günlük & 1 günlük & 4 günlük & 4 günlük \\
\hline Sitenin son güncellenme bilgisi & $\times$ & $\times$ & $\times$ & $\times$ & $\times$ \\
\hline Günlük haberler veriliyor mu? & + & + & + & + & + \\
\hline Anlık (son dakika) haberler veriliyor mu? & + & + & + \\
\hline
\end{tabular}

İçerik kriterinin beşinci başlığı güncelliktir. Güncellik web sitelerinin kurumsal itibari açısından önemlidir. Hedef kitlenin siteye tekrar gelmesi isteniyorsa site s1k s1k değiştirilmelidir. Sitenin güncelliği için basın bültenleri, kurum duyuruları ve özel günler ile ilgili bilgiler, daha sık güncellenerek değiştirilmeli ya da kaldırılmalıdır. Aynı şekilde sitenin kendisi de yılda en az bir kez elden geçirilmelidir. Sitede yer alan haberler gazeteciler, yatırımcılar ve diğer kamular için farklı enformasyon sağlamaya müsait hale getirilmelidir. $\mathrm{Bu}$ yolla sürekli güncellenen site içeriği ile hedef kitleye güven duygusu aşılanmalıdır (Koçer, 2019: 1483). Bu bilgilerden yola çıkarak haber siteleri güncellik kriterine göre değerlendirildiğinde tablodan da görüldüğü üzere Sadece Dideban gazetesinin sitesi güncellik kriterinin alt başlıklarından günlük haberlere yer vermektedir. Doğru Haber ve Beşminare gazetesi siteleri günlük, Şark gazetesi sitesi 2 günlük, Dideban ve Yeni Bitlis gazetesi siteleri 4 günlük süreyle güncellenmektedir. Son dakika haberlerine ise tüm siteler yer vermektedir. Buna karşın sitenin son güncellenme bilgisine sadece Yeni Bitlis gazetesi sitesinde rastlanmaktadir. 


\section{4. İÇERÍK}

\section{F. HABER YAZIM KURALLARI VE DIL KULLANIMI}

\section{İşaretler: var, evet: +}

Doğru Haber Şark Beşminare

Dideban Yeni Bitlis

yok, hayır: $x$

\begin{tabular}{|c|c|c|c|c|c|}
\hline Haberlerin yazım kurallarına uygun yazılmış mı? & + & + & + & + & + \\
\hline Haberlerin yapısı doğru ve açık anlamaya uygun mu? & + & + & + & + & + \\
\hline Gramer kullanımı doğru mu? & + & + & + & + & + \\
\hline Noktalama işaretleri doğru mu? & + & + & + & + & + \\
\hline İmla hataları var mi? & $x$ & $x$ & $\times$ & $x$ & $x$ \\
\hline Uzun ve eksik paragraflar var mi? & $x$ & $\times$ & $\times$ & $x$ & $x$ \\
\hline Haber tüm detayları ile veriliyor mu? & + & + & + & + & + \\
\hline $\begin{array}{l}\text { Haber, Başlık-Spot (haber özeti) haber metni olarak } \\
\text { verilmiş mi? }\end{array}$ & + & + & + & + & + \\
\hline
\end{tabular}

İçerik kriterinin altıncı başlığı haber yazım kuralları ve dil kullanımıdır. Herhangi bir haber sitesinde muhabir tarafından toplanan haberlerin hiçbiri direkt dolaşıma sokulmaz. Bunun öncesinde bazı kontrollerin yapılması gereklidir. Bu gerekliklerinden biri de haber yazım kuralları ve dil kullanımı ile ilgilidir. Haber kaynaklarında bu işi editörler yapmaktadır. Editör muhabir tarafından dünyada gerçekleşen politik, ekonomik, toplumsal, kültürel alanlardan toplanan haberleri redaksiyon eder. Haberin redakte edilmesi haberin önemli aşamalarından biridir. İster yeni, ister eski bir gazetecinin elinden çıkan her haber olduğu gibi yayınlanmaz. Ancak bu olgu, haberin sansür edildiği veya özüne müdahalede bulunulduğu anlaminda okunabilecek bir niteliğe sahip değildir (Kaplan, 2003: 88). Siteler bu kriterin alt başlıkları olan haber yazım kurallarına uygunluk, haber yapısının doğruluğu ve açıklığı, gramer ve noktalama doğruluğu, uzun ve eksik paragraflar, haberlerin tüm detayları ile verilmesi ve haber, başlık-spot (haber özeti) haber metni olarak verilmiş mi? başlıkları açısından paralellikler göstermektedirler.

\section{TEKNIK ÖZELLÍKLER}

\section{İşaretler: var, evet: +}

Doğru Haber Şark Beşminare Dideban Yeni Bitlis

yok, hayır: $x$

\begin{tabular}{|c|c|c|c|c|c|}
\hline Bütün linklerin çalışması & + & + & + & + & + \\
\hline Bağlantıları yeni pencerede açma & + & + & + & + & + \\
\hline Ana sayfaya dönüş kolaylığ 1 & + & + & + & + & + \\
\hline Ekran çözünürlüğü bilgisi & $x$ & $x$ & $x$ & $\times$ & $\times$ \\
\hline Geri bildirim (feedback) butonu ve işlevselliği & + & + & + & + & $x$ \\
\hline Yazıcı çıktısı alma butonu & + & + & + & + & + \\
\hline Haber bir başkasına gönderme butonu & $x$ & $x$ & $x$ & $x$ & $x$ \\
\hline S1k kullanılanlara ekleme butonu & $\times$ & $\times$ & $\times$ & $\times$ & $x$ \\
\hline Sikça sorulan sorular sayfası & $x$ & $x$ & $x$ & $x$ & $x$ \\
\hline Haberleri masa üstüne indirme özelliği & $x$ & $\times$ & $x$ & $x$ & $x$ \\
\hline Giriş sayfası yapma butonu & $\times$ & $x$ & $x$ & $\times$ & $x$ \\
\hline Yararlı site linklerine yer verme & $x$ & $\times$ & $x$ & $\times$ & $x$ \\
\hline Haberleri sitene ekle butonu & + & $x$ & $x$ & $\times$ & $x$ \\
\hline
\end{tabular}

Formun beşinci bölümünü "teknik özellikler" kriterleri oluşturmaktadır. Bilindiği üzere Türkiye'de medya yapılanmasında yer alan yerel gazeteler teknik açıdan sorunlar yaşamaktadırlar. Bu bağlamda yerel gazetelerde 
internet kullanımı kamuoyu oluşturma açısından önemlidir. İnternet kullanımının yoğun bir teknik bilgi gerektirdiği ise aşikârdır. Bu yönüyle yerel gazete çalışanlarının teknik olanaklara kullanabilmesi gerekliliği ortaya çıkmaktadır. Hülasa teknik detaylar haber sitelerinin ve hedef kitlenin etkileşim içinde olmasını sağlayan başat olanaktır (Gürcan ve Bayram, 2005: 56). Siteler bu kriterlere göre değerlendirildiğinde; bütün linklerin çalışması, bağlantıları yeni pencerede açma, ana sayfaya dönüş kolaylığı, geri bildirim (feedback) butonu ve işlevselliği ile yazıcı çıktısı alma butonu özelliklerine rastlanmıştır. Ekran çözünürlüğü bilgisi, haberi bir başkasına gönderme butonu, sık kullanılanlara ekleme butonu, sıkça sorulan sorular sayfası, haberleri masa üstüne indirme özelliği ve giriş sayfası yapma butonunun ise kullanılmadığı tespit edilmiştir. Buna karşın haberleri sitene ekle alt başlığının sadece Doğru Haber tarafından kullanılması dikkat çekmektedir.

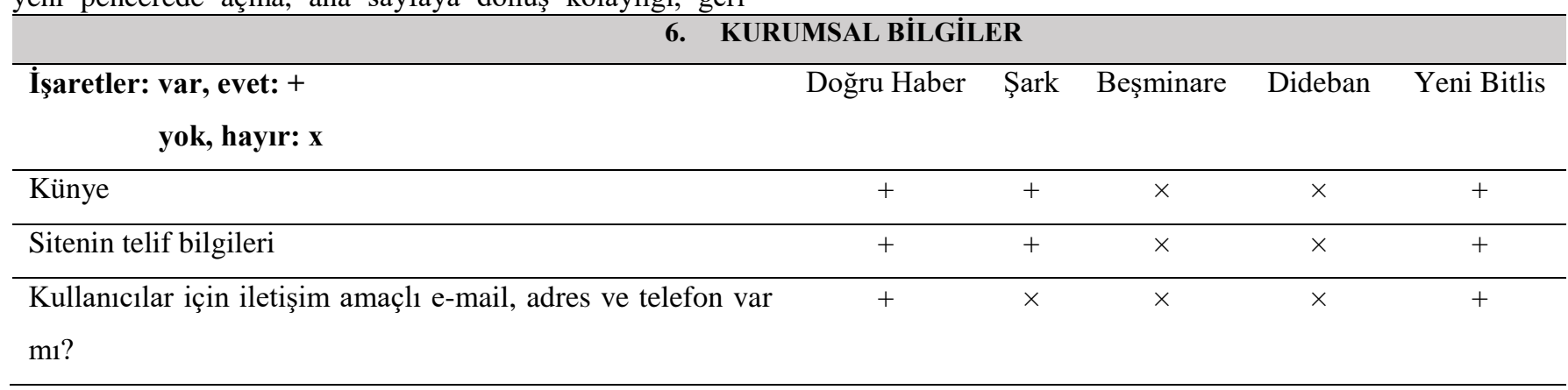

Formun altıncı bölümünde "kurumsal bilgiler" kriterine yer verilmiştir. Kurumsal bilgiler internet hukuku kavramıla bağlantılı olarak ortaya çıkan etik bir konudur. Haber siteleri sorumluluk bilinciyle hareket ederek, kurumsal bilgilerine yer vermelidirler. Kurumsal bilgiler, kurumların kendilerini nasıl gördükleri ile yakından ilgilidir. Kurumlar da bireysel gibi, kendilerini ifade edebilmelerinde kurumsal bilgiler büyük rol oynamaktadır. Haber siteleri kurum kültürünü ve felsefesini örgüt üyeleri aracılığıyla yaşatırlarsa nasıl dünyada kurumsal kimliklerini elde edebilirler. Siteler özellikle tasarım unsurları ile ön plana çıkmalıdırlar. Çünkü tasarım unsurları kurumun görünün yüzüdür. Kurumun amblem/logosu, kurum renkleri, kurumsal web sitesi mutlaka olmalıdır. Ayrıca kurumun görünmeyen unsurları olan kurum kültür, felsefesi ve davranışlarını yansıtan yönergeler, açıklamalar ve törenlere kurum web sitesinde yer verilmelidir (Koçer, 2017: 756). Bu başlıkta künyeye ve sitenin telif bilgilerine Doğru Haber, Şark ve Yeni Bitlis gazetelerinin yer verdiği, Beşminare ve Dideban gazetelerinin ise yer vermediği görülmektedir. Kullanıcılar için iletişim amaçlı e-mail, adres ve telefon bilgilerine de Doğru Haber ve Yeni Bitlis sitelerinin yer verdiği görülmektedir.

\begin{tabular}{|c|c|c|c|c|c|}
\hline 7. & ETKILLEŞIMLILIK & & & & \\
\hline $\begin{array}{r}\text { İşaretler: var, evet: }+ \\
\text { yok, hayır: } x\end{array}$ & Doğru Haber & Şark & Beşminare & Dideban & Yeni Bitlis \\
\hline Editöre doğrudan mail & + & + & $\times$ & $x$ & $x$ \\
\hline Yazarlara doğrudan mail & $\times$ & $\times$ & $\times$ & $\times$ & $\times$ \\
\hline Chat (sohbet) odas1 & $x$ & $x$ & $x$ & $x$ & $\times$ \\
\hline Okuyucuyu inceleyen araştırma/ istatistik havuzu var mı? & $x$ & $x$ & $x$ & $x$ & $x$ \\
\hline Okuyucu için forum köşesi & $x$ & $\times$ & $x$ & $\times$ & $x$ \\
\hline
\end{tabular}

Formun yedinci bölümünde "etkileșimlilik" kriterine yer verilmiştir. Bilindiği üzere haber siteleri ile hedef kitle arasında iletişimin sağlanabilmesi için internet gerekli bir teknolojidir. İnternet ve iletişim teknolojilerinin gelişimi, bireysel erişimin olmazsa olmazı web'in icadı çift ve çok yönlü iletişim modelini ortaya çıkarmıştır. Bu gelişmelerin bir sonraki teknolojisi ise yeni medya kavramı ile ifade edilmektedir. Yeni medya teknolojisi bireylerin çevrim içi ortamlarda yerini alabilmesini sağlamıștır. Bir web sitesinin hedef kitle ile etkileşim sağlayabilmesi ise kullanıcılarına elektronik posta, online anketler ya da forumlar aracılığıyla görüşlerini aktarma imkânı sunması ile gerçekleşmektedir. Bir başka ifadeyle haber siteleri tüm içerikleri ile kullanıcılarına geri dönüș imkânı sağlamalıdır. Bu durum aynı zaman sitede yer alan haberlerin yorumlanabilmesi ve paylaşılabilmesi de ön olana çıkarmaktadır
(Değirmencioğlu, 2011: 26). Bu bağlamda yazarlara doğrudan mail, Chat (sohbet) odası, okuyucuyu inceleyen araştırma/istatistik havuz ve okuyucu için forum köşesi başlıkların tüm sitelerce kullanılmadığı; editörlere doğrudan mesaj başlığının ise sadece Doğru Haber ve Şark gazetesi sitelerin tarafından kullanıldığı görülmektedir.

\section{Sonuç ve Değerlendirme}

Tarihinin başından beri insanlar birbirleriyle iletişim kurma ihtiyacı duymuşlardır. Bu iletişim kurma istenci zaman içerisinde çeşitlenerek değişiklikler göstermiştir. $\mathrm{Bu}$ gereksinim mağara duvarlarına çizilen resimlerle, yüz yüze iletişimle, yazı, telgraf, telefon vb. araçlarla giderilmiştir. Günümüze geldiğimizde internet, insanların birbiri ile iletişime geçmesine olanak sağlayan en cazibeli araç olarak 
görülmektedir. Çünkü internet sayesinden kullanıcılar birçok imkândan faydalanabilmektirler. Akıllı telefonlar, tabletler, bilgisayarlar vb. mobil cihazlar aracılığıyla kolaylıkla arkadaş edinme, e-posta gönderme, sesli ya da görüntülü arama yapma, kişisel bloglar açarak kendilerini ifade etme, gazete-dergi okuma, yemek siparişinde bulunma, TV izleme ya da radyo dinleme imkânı bunlardan bazılarıdır. Süreç içerisinde internet teknolojilerindeki gelişmelere koşut olarak internet kullanımının artacağını söylemek olasıdır. Bu noktada insanlar birbirilerinden haberdar olmak ya da bilgiye ulaşmak için çevrim içi yayın yapan hem gazeteler hem de haber sitelerini takip etmek durumdadırlar. Dolayısı ile çevrim içi yayın yapan gazeteler teknik özellikleri başta olmak üzere içerikleriyle de insanların birbirileriyle etkileşime geçmesine imkân sağlamak zorundadırlar.

$\mathrm{Bu}$ çalışmada Bitlis şehir merkezinde günlük olarak faaliyet gösteren yerel gazetelerin (Doğru Haber, Şark, Beşminare, Dideban, Yeni Bitlis) internet ortamındaki görünümleri biçim ve içerik açısından incelenmiştir. Erişilen bilgiler maddeler halinde şu şekildedir:

- Araştırmada incelenen tüm sitelerin kullanıcılara erişim noktasında kolaylıklar sağladığ görülmüştür.

- Sitelerin web server hızları incelendiğinde Doğru Haber sitesinin kullanıcıları tatmin etmediği tespit edilmiştir.

- Şark gazetesinin sitesi dışında tüm sitelerin ana sayfa görünümleri kullanım noktasında kullanıcılara kolaylıklar sağlamışlardır.

- Tüm sitelerin haber içeriklerinde fotoğraf kullanmaya özen gösterdikleri tespit edilmiştir. Bu durum haberin gerçekliğini arttırmaktadır.

- Kullanım kolaylığı açısından tüm siteler site içi aramaya olanak sağlarken, sitelerden hiçbirinin arşive yer vermemeleri eksikliktir.

- Beşminare ve Dideban gazetesi sitelerinin sayfaların içeriğinden sorumlu kişilere yer vermemeleri kullanıcıların sitelere karş1 güvensizlik hissetmelerine neden olabilir.

- Tüm sitelerin hazır içerik yönetim sistemi kullandıkları tespit edilmiştir. Birbirinin benzeri olan bu sistemler, sitelerin kurumsal imajı açısından sıkıntılar yaşadıklarını göstermektedir.

- Haber sitelerinde yayınlanan haberlerde kaynak kullanımı okuyucuların haberlere olan güvenini doğrudan etkilemektedir. Tüm sitelerin yayınladıkları haberlerde kaynaklarını belirtmedikleri görülmüştür. Bu durum da siteler için önemli bir eksiklik olarak değerlendirilebilir.

- Mesaj panosu, anket ve forum gibi özellikler sadece Doğru Haber ve Şark gazetesi siteleri tarafından kullanılmaktadır. Bu durum sitelerin kullanıcılar ile etkileşim kurmaları önünde engeldir.

- Tüm sitelerde, haber sitesinin amaçlarının, yayın politikasının tanımlandığı bir sayfa var olması gerekirken hiçbir sitede bu başlığa yer verilmemiştir.

- Tüm sitelerin haber yazım kuralları, gramer kullanımı ve imla kuralları açısından yayınlanan haberlerin başarı oldukları tespit edilmiştir. $\mathrm{Bu}$ durum haberlerde anlatılmak istenenin anlaşılması noktasında önem arz etmektedir.
- Haberin güncel olması haberlerin okunmas1, dinlenmesi ya da izlenmesi açısından önem arz etmektedir. Bu noktada tüm sitelerin güncel ve son dakika haberlerine yer vermeleri siteler açısından okur ilgisini çekme hususunda önemlidir.

- Bir sitenin etkileşimli olabilmesi için kullanıcıların e-posta, forum köşesi, Chat ya da çevrim içi anketler yoluyla görüşlerini aktarma imkânı sunması gerekmektedir. Elde edilen bulgular 1şı̆̆ıında açıkça görülmektedir ki; tüm gazeteler okuyucu etkileşimi konusunda sıkıntılar yaşamaktadırlar.

Sonuç olarak yukarıda maddeler halinde verilen tespitlerden açıkça anlaşıldığı üzere, Bitlis yerel medyasının yenileşme pratiklerinde sıkıntılar görülmektedir. Bu durum Bitlis yerel medyasına özel değildir. Yerel medya hakkında yapılan benzer çalışmalar incelendiğinde bazı farklar olmakla beraber genel olarak aynı sıkıntıların yaşandığı görülmektedir. Örneğin Gürsoy Değirmencioğlu (2011) tarafından Kocaeli yerel gazetelerinin (Özgür Kocaeli, Kocaeli Gazetesi, Bizim Kocaeli) internet siteleri üzerine çalışma yapılmıştır. $\mathrm{Bu}$ çalışmada, çalışmamızdan farklı olarak etkileşimlilik kriterinin söz konusu gazetelerce etkin bir şekilde kullanıldığı açıklanmıştır. İçeriksel anlamda çalışmamızla ile benzer şekilde üç gazetenin de ana sayfalarında haberlerde metin ve fotoğraf dışında herhangi bir ses ya da video dosyasına yer vermedikleri tespit edilmiştir. Yine çalışmamıza benzer şekilde Kacur ve Bostanc1 (2012) tarafindan Kayseri'deki yerel gazetelerin internetteki görünümleri üzerine bir çalışma yapılmıştır. Çalışma sitelerin kullanım kolaylığ incelendiğinde çalışmamızla benzer şekilde bazı sitelerin kullanıcılara kolaylıklar sağladığı, bazılarının ise sağlamadığı sonucu elde edilmiştir. Yine çalışmamızla benzer şekilde Kayseri yerel basınında da amaç ve yayın politikasının yer verme noktasında noksanlıklar tespit edilmiştir. Bir diğer tespit ise Kayseri'de günlük yayın yapan gazetelerin internet sitelerinin büyük bölümünün Bitlis'tekiler ile benzer şekilde hazır içerik yönetim sistemi kullandıkları ve bu tercihlerinde düşük maliyetli ya da ücretsiz uygulamaları tercih ettikleri görülmektedir. Benzer başka bir çalışmada Gürcan ve Bayram (2005) tarafindan Denizli, Eskişehir ve Erzurum yerel medyasından toplam 16 site örneklem olarak incelenmiştir. Çalışmamızla benzer şekilde incelenen 16 sitenin de genel görünüş kriteri açısından zemin rengi olarak beyazı kullandıkları, dil seçeneklerinin olmadığı, haber sitesinin amaçlarının/yayın politikasının tanımlandığı bir sayfaya yer verilmediği, gramer ve yazım hatalarından arındırıldığı görülmüştür.

Neticede gerek Bitlis özelinde gerek yapılmış benzer çalışmalardan hareketle internet üzerinden yerel haber veren sitelerin, interneti daha etkin kullanmaları gerektiği açıktır. $\mathrm{Bu}$ bağlamda yerel gazete yöneticilerinin okurlarının kullanım alışkanlıklarını göz önünde bulundurmaları, internete hâkim uzman kadroyu oluşturması ve son olarak site içeriklerini güncel bilgi teknolojilerine uygun olarak sürekli güncellemeleri gerekmektedir.

\section{Kaynakça}


Aktaş, C., (2007). İnternet'in gazeteciliğe getirdiği yenilikler. Selçuk İletişim, 5(1), 30-41.

Atabek, N. (1994). Gazetecilikte tarafsızlık. Marmara İletişim Dergisi, 1, 23-36.

Atun, A., (2005). Yerel medya çalışanlarının eğitim ihtiyacı ve yerel medya enstitüsü. İletişim Araştırmaları, 3(1-2), 75-104.

Aydoğan, A. (2012). Basın endüstrisinde dönüşüm ve internet gazeteleri (Doktora Tezi). Ankara: Ankara Üniversitesi.

Banar, S. (2006). Türkiye'de haber verme işlevinin kişilik hakları ve etik yaklaşımla değerlendirilmesi. Dumlupınar Üniversitesi Sosyal Bilimler Dergisi, 15, 125-138.

Baş, T. (2002). Öğretim üyelerinin iş tatmin profillerinin belirlenmesi. DEÜ İktisadi ve İdari Bilimler Fakültesi Dergisi, 17(2), 19-37.

Bayram, M., Yayl1, A. (2009). Otel web sitelerinin içerik analizi yöntemiyle değerlendirilmesi. Elektronik Sosyal Bilimler Dergisi, 8(27), 347-379.

Bulunmaz, B., (2005). İnternet gazeteciliğinin medya dünyası içindeki rolü ve ekonomik boyutları. Niğde Üniversitesi İktisadi ve İdari Bilimler Dergisi, 9(1), 229235.

Çevikel, T. (2004). Türkçe haber siteleri ve Türkiye'de internet gazeteciliğinin gelişimini sınırlayan faktörler. Galatasaray Üniversitesi İletişim Dergisi, 1, 174-163.

Çınar, M. (2019). Yerel internet gazeteciliği: Çorum örneği. Üsküdar Üniversitesi Iletişim Fakültesi Akademik Dergisi Etkileşim, (3), 156-177.

Dağtaş, E., Aydın, N. (2017). Yerel magazin basınının ekonomi politiği: Eskişehir'de yayımlanan magazin dergilerinin sektörel çözümlemesi. Global Media Journal TR Edition, 7(14), 23-51.

Değirmencioğlu, G. (2011). Yerel basında yeni medya ve sosyal paylaşım sitelerinin kullanımı: Kocaeli'de yayımlanan yerel gazetelerin internet siteleri üzerine bir inceleme. AJIT-e: Online Academic Journal of Information Technology, 2(5), 19-31.

Dikener, O. (2011). İnternet reklamcılığında web sitesi tasarımının önemi. Erciyes İletişim Dergisi, 2(1), 152166.

Erdoğan, İ. (2006). Türkiye'de ulusal ve yerel gazetelerin habercilik anlayışları: deprem haberlerinin karşılaştırmalı analizi. Selçuk İletişim, 4(3), 51-64.

Ergün, M., Ergün, E. (2008). Web sitelerinin çeşitli özellikleri ve eğitim kurumları web sitelerine yansımaları. Kuramsal Eğitimbilim, 1(1), 2-19.

Esgin, E., Baba, Z., Aytaç, N., Turan, E. (2011). İnternet tabanlı kaynakların doğruluğu ve güvenilirliği hakkındaki farkındalığın incelenmesi. 5th International Computer \& Instructional Technologies Symposium, Elazı̆̆, Türkiye.

Gezgin, S. (2007). “Türkiye'de yerel basın”. Türkiye'de yerel basın içinde. Gezgin, S. (Ed.). İstanbul, İstanbul Üniversitesi İletişim Fakültesi Yayınları, 177-196.
Girgin, A. (2001). Türk Basın Tarihi’nde Yerel Gazetecilik. İstanbul: İnk1lap Kitapevi.

Güçdemir, Y. (2003). Bilgisayar ağları internetin gelişimi ve bilgi kirlenmesi. İstanbul Üniversitesi İletişim Fakültesi Dergisi, (17), 371-378.

Gürcan, İ. H. (1998). Sanal gazete ve gazetecilik. Kumru Dergisi, 15, 143-153.

Gürcan, İ. H. (2003). Haber sitelerinde içerik ve tasarıma yönelik değerlendirme ölçütlerine bir yaklaşım. Selçuk İletişim, 2(4), 90-99.

Gürcan, İ., Bayram, F. (2005). Yerel haberlerin internet ortamında görünümleri- Denizli, Eskişehir ve Erzurum örnekleminde bir değerlendirme. Selçuk İletişim, 3(4), 53-62.

Kacur, M., Bostanc1, M. (2012). "Kayseri'deki yerel gazetelerin internetteki görünümleri üzerine bir analiz”, tarih içinde Kayseri basını. Çakır, H., Aydın, H. (Ed.). Konya: Palet Yayınları, 397-427.

Karaduman, M. (2005). Internet ve gazetecilik, yeni iletişim teknolojileri ve medya. Sevda Alankuş (Der.). İstanbul, IPS İletişim Vakfı Yayınları, 1431-153.

Karaduman, M. (2017). Yerel medya çalışanlarının eğitim düzeyleri ve mesleki yeterlilikleri: Antalya örneği. Akdeniz Üniversitesi İletişim Fakültesi Dergisi, 284301.

Kaplan, S. (2003). Hürriyet gazeteciliği, İstanbul: Doğan Kitapçılık.

Kayacan, İ. (1996). Basınımızın Anadolu cephesi, Ankara: Ece Yayınları.

Kılıç, S. (2015). Türkiye'de geleneksel gazetecilik anlayışına alternatif bir yaklaşım: internet gazeteciliğ $i$ (Doktora Tezi). Antalya: Akdeniz Üniversitesi.

Koç, P. (2017). Ana akım medyanın internet haber sitelerinde çevrimiçi oyunlara yönelik bağımlılık temsili (Yüksek Lisans Tezi). Ankara: Hacettepe Üniversitesi Sosyal Bilimler Enstitüsü.

Koçak, A., Arun, Ö. (2006). İçerik analizi çalışmalarında örneklem sorunu. Selçuk İletişim, 4(3), 21-28.

Koçer, S. (2019). Halkla ilişkiler bakış açısı ile kurumsal web sitelerinin incelenmesi. Uluslararast Sosyal Araştırmalar Dergisi, 12(62), 1479-1494.

Koçer, S. (2017). Kurumsal web sitelerinin kurum kimliği açısından incelenmesi: en çok tercih edilen üniversiteler üzerine bir analiz. Uluslararası Sosyal Araştırmalar Dergisi, 10(53), 756-772.

Korkmaz, A. (2009). İnternet gazeteciliğinin kamuoyu oluşumuna etkisi. Erciyes Iletişim Dergisi, 1(2), 6-19.

Kösedağ, M. S. (2016). Türkiye'deki ulusal ve yerel gazetelerin siyasal gündemlerinin karşılaştırılması. Uluslararası Sosyal Araştırmalar Dergisi, 9(42), 15861603.

Kurtbaş, İ. Doğan, A. Göker, G. (2009). Yerel medya sorunsalları ve sektör çalışanlarının sorunlara bakışları 
"Elâzığ ili örneği. Erciyes Üniversitesi İletişim Fakültesi Dergisi, 1(2), 20-41.

Mumay, B. (2003). Internet gazeteciliği ve haberin değişen işlevi (Yüksek Lisans Tezi). İstanbul: İstanbul Üniversitesi.

Öztürk, G. (2017). Sözlü iletişimden matbaaya: iletişim devrimleri ve toplum. The Turkish Online Journal of Design, Art and Communication TOJDAC, 7(2),317-327.

Öztekin, H. (2008). Haber üretim sürecinde medyanın ekonomi politiği: Star gazetesi örneği. Ístanbul Üniversitesi İletişim Fakültesi Dergisi, (32), 29-144.
Ural, S. Hangül, N. (2019). Hatay'da yerel basın (19391950). Kafkas Üniversitesi Sosyal Bilimler Enstitüsü Dergisi, 23, 257- 277.

Yazıcı, H. A. (2014). Yerel basının özellikleri ve sorunlarl: Sakarya basını üzerine bir araştırma (Yüksek Lisans Tezi). İstanbul: İstanbul Üniversitesi.

Yurdigül, Y, Yüksel, H. (2012). Gazeteciliğin dönüşümü: yeni medyaya entegrasyon sürecinde değişen habercilik pratikleri. Akdeniz Üniversitesi İletişim Fakültesi Dergisi, 18, 140-161. 


\section{Extended Absract}

The subject of reaching the knowledge and disseminating the acquired knowledge, has been regarded as an important need for humanity since the very first days of history. With today's new media order, the means of communication which encompasses the world like a rambler and answers the said need of the humanity, is the Internet. Internet, arising in the late 20th century, has successfully integrated itself to the world as a means of communication. Internet is being used with many purposes such as shopping, trade, banking, information storing, education, communication, receiving news and knowledge, etc. Internet has also pioneered in fast developments in the field of information technologies. Additionally, Internet has successfully reached every home and paved way for internet journalism to arise as a new type of journalism in regards to mass communications tools being obligated to integrate this new technology into their systems. Internet journalism, is the transfer of knowledge to the audience in written, visual or audial form by using various methods of journalism. This type of journalism, even though it has emerged as transferring the exact knowledge from the traditional newspaper to the internet, has showed significant developments which surpassed the traditional journalism. This new type of journalism created conveniences for both the journalists and the audience. Thanks to Internet journalism, newspapers have many opportunities such as reaching a larger volume of audience, to able to instantly update the news, to swiftly create streams, etc. In addition to these opportunities, media outlets are able to interact with their audience through their internet pages, to receive their feedback and to create multimedia by uploading multimedia contents which include text, audio and videos at the same time, to their Internet pages. These new opportunities are also important for local media outlets who strive to inform the public about the decisions made by the local government, problems, incidents, economic and social events in their respective cities and towns. Local media outlets; thanks to these new opportunities, have the opportunity to spread the incidents, problems in their respective regions, their cultural values to the globe. Therefore, local newspapers are obliged to closely monitor the globe for events with journalism value. In an atmosphere which internet journalism continues to develop and to become widespread, it is an important matter as to whether the local newspapers are adapting to this new condition. Accordingly, in the new media world which internet journalism improves its significance, innovation practices of the local newspapers in Bitlis province have been chosen as the subject of evaluation. The fact that no adequate study on the local media of Bitlis, can be found in the literature has been evaluated as a deficiency. This condition creates the importance of this study. The main purpose of the study is to describe the online appearances of the newspapers in Bitlis which are being published on a daily basis, in regards to their conte and formation. Under the scope of this purpose, online visuality of the newspapers, their web sites, accessibility to these web sites, general visuality, their ease of use, their contents (competence, truthfulness, objectivity, scope, timeliness, writing rules for news and use of language), technical features, corporate details have been examined in regards to interactions. As the method, internet pages of Doğu Haber, Şark, Beşminare, Dideban and Yeni Bitlis newspapers which are being published in Bitlis provincial centre on a daily basis, have For the analysis of the data resulting from the content analysis, evaluation form crated by Gürcan in regards to contents and design of the internet pages of the newspapers, has been primarily employed. Primarily, form consisted of seven basic categories including accessibility to the site, general appearance, ease of use, contents, technical features, corporate details and general evaluation and commentary. This form has been expanded by Gürcan and Bayram in the following years. In the last format of the said evaluation form, general evaluation and commentary title has been changed to interactivity whereas other titles of the form stayed the same. As a result, online appearances of the local newspapers (Doğru Haber, Şark, Beşminare, Dideban, Yeni Bitlis) in Bitlis provincial centre have been examined in regards to their format and contents and the following results have been achieved:

- It has been observed that all the websites examined within the study provides conveniences in regards to easy access of their users.

- Upon examining the speed of the web serves of the sites, it has been identified that Doğru Haber website is not able to satisfy their users.

- Except for Şark Gazetesi, home page appearances of all the websites have provided usage conveniences for their usage.

- It has been observed that all the websites have emphasized on using visuals. This increases the actuality of the news.

- In regards to ease of use, while all the websites enable insite search, it is deficiency that none of them provides archives.

- The fact that Beşminare and Dideban do not include their content responsible in their web pages, may create lack of trust for their users.

- It has been observed that all the websites use content management system. These systems which are similar to each other, signify that websites are having problems regarding their corporate image.

- Usage of sources for the news published on news websites, directly influence the trust of their users regarding the said news. It has been observed that none of the websites cite sources for their published news. This can be considered as an important deficiency for websites.

- Only Doğru haber and Şark websites use features such as message panel, surveys and forums. This is an obstacle for websites to interact with their readers.

- While all of the websites need to have a page in which the purpose and publishing policy of the newspapers are explained, none of them includes this title.

- It has been observed that all of the websites are successful in regards to complying with spelling rules, grammar usage and syntax rules for the news published on their websites. This is important concerning the understanding of the contents of the news.

- News being up to date is important in regards to news being read, listened or watched. Concerning this, it is important for all the websites to include current and breaking news in regards to draw the attention of the readers.

- In order for website to become interactive, it is necessary for users to express their opinions via e-mail, forum blogs, chat or online surveys. According to the results obtained, it is obvious that all the newspapers are having problems with reader interactions. 